\title{
Demographic Characteristics and Non-economic Outcomes of Women Entrepreneurs with Moderation of Barriers: The Case of Small Enterprises in Rural Coastal Area of Indonesia
}

\author{
Ika Nur Putriantini* \& Yoshi Takahashi \\ ${ }^{1}$ Technical Inspection Unit of Yogyakarta, Fish Quarantine and Inspection Agency, Ministry of Marine Affairs and Fisheries of Indonesia, \\ Yogyakarta Special Region, Indonesia \\ 2Graduate School of International Development and Cooperation, Hiroshima University, Kagamiyama, Higashi Hiroshima-shi, Hiroshima, Japan \\ Corresponding author, e-mail: ikanurputri@gmail.com
}

Submitted 15 August 2019 Revised 02 January 2020 Accepted 30 June 2020

\begin{abstract}
As a means of escaping poverty, women often become entrepreneurs while maintaining a traditional occupation and this may limit their ability to take full advantage of entrepreneurial opportunities. This study provides a relevant examination of women entrepreneurs in a rural coastal area of a developing country; as such, it helps contribute to perspectives on demographic characteristics, on the barriers to, and the non-economic outcomes of women entrepreneurs in the rural areas of developing countries. The results demonstrate that all the demographic characteristics of women entrepreneurs correlate significantly with non-economic outcomes. Meanwhile, only three of five barriers were found to moderate the relationship between the demographic characteristics and non-economic outcomes. These barriers are likely to affect the real-world relationship between the demographic characteristics and non-economic outcomes. For that reason, great attentions need to be given for policy makers to improve the presence of small enterprises.
\end{abstract}

Keywords: Women entrepreneurs; demographic characteristics; non-economic outcomes; barriers; moderation; rural; coastal; Indonesia

\section{INTRODUCTION}

The government of Indonesia has the vision of poverty elimination and increases shared prosperity. One way of achieving this is to support micro, small, and mediumsized enterprises (MSMEs). One of the highest-return opportunities available in supporting MSMEs in Indonesia comes from supporting women entrepreneurs (International Finance Corporation, 2016). Nowadays, women represent about two-third that of men involved in entrepreneurial activity as the number of women entrepreneurs worldwide continues to steadily increase and also the public is becoming more receptive to and encouraging of these women entrepreneurs, given their valuable contribution to the economy and society (Minniti \& Arenius, 2003). As on Winn (2004), women entrepreneurs have also made significant strides towards gender-based equality, in areas such as education and the workplace; meanwhile, their position as the family "bedrock" in terms of parenting and homemaking remains relatively unchanged.

Women entrepreneurship is considered an important tool in enabling women empowerment, which predominantly holds roles in informal sectors, and they tend to create new businesses around their family environment. They tend to have smaller businesses with less capital, have lower revenues and fewer employees, and work in lower-profit industries, as per McCracken et al. (2015), are thought to be more risk-averse than men when making financial decisions. It seems that women entrepreneurs also tend to be sole owners and have less managerial experience in small and medium-sized enterprises (SMEs) (Bird, 1989). Additionally, Loscocco \& Robbinson (1991) found that women-owned businesses tend to concentrate in the retail trade and service sector. It also needs to be highlighted that the key motivation for women in entering entrepreneurship is not making money: non-economic factors proved more important and it seems to be stronger motivators of women entrepreneurs (McGowan et al., 2012). Meanwhile, Minniti (2010) has also demonstrated that most researchers agree that the role played by women entrepreneurs in the context of economic development is crucial.

This study provides a relevant study of women entrepreneurship in a rural area of a developing country, contributes to perspectives on demographic characteristics and the non-economic outcomes of women entrepreneurs in the rural areas of developing countries by integrating the moderation of existing barriers, and such research has not been undertaken in a similar geographical area.

In this study, section 2 deals with literature review to support the state of the author. Then, Section 3 highlights the method of the study. Section 4 addresses results, and also section 5 addresses discussion. Concluding remarks are drawn in Section 6.

\section{Literature review}

Women's entrepreneurship in Indonesia started to emerge as a means of surviving poverty, especially in rural areas. Furthermore, Marsden (1999) found that rural areas have become multi-purpose spaces used for relaxation, entertainment, working, and living, and Halfacree (2006) similarly found that the growing demand made on rural regions-with the aid of society-as tourism and recreation sites, has converted the countryside from a predominantly production-based (i.e., agricultural) area to a predominantly consumption-oriented space. This also became trends in most of the rural coastal area in Indonesia (Puskompublik, 2014). Moreover, as Markantoni \& Van Hoven (2012) point out, rural 
communities can provide social and emotional services that encourage a household to remain in an area of economic decline, as small-scale economic activities can contribute significantly to quality of life and well-being. That study showed that women's embeddedness in local communities, as well as their greater reliance on smaller strong-ties networks, produces profound effects on their immediate surroundings. Welfare resulting from women entrepreneurs tends to be larger than that resulting from the activities of men. Thus, (Acs et al., 2004) confirm more that the presence of women entrepreneurs tends to be more significant in countries with low per-capita gross domestic product.

\section{Demographic characteristics of women entrepreneurs}

Every woman entrepreneur possesses demographic characteristics that enable and help her perform activities essential to produce related products and services. Women entrepreneurs have also made significant strides towards gender-based equality. Manzanera-Roman \& Brandle (2016) identify a gender discourse that reflects how entrepreneurs provide abilities considered as "belonging" to women. Women entrepreneurs tend to center on perseverance: the ability to treat people with empathy or social sensitivity, and skills in dealing with people and communication. Based on Bass et al. (1996), women entrepreneurs display distinct abilities in exhibiting more "transformational" leadership, compared to their male counterparts-that is, a management style that seeks to foster positive interactions and trust relations with or among subordinates, to share power and information, and to encourage employees to subordinate their personal aims and interests to collective ends. The similar result also studied by (Buttner, 2001) and (Burke \& Collins, 2001).

\section{Age}

A number of individual factors may play roles in women entrepreneurs' outcomes. According to many previous studies, age is a key demographic characteristic in understanding entrepreneurial behavior and intentions. Research findings have highlighted that the most active entrepreneurship is seen among individuals at the age of 25 and/or older (Levesque \& Minniti, 2006). Azoulay et al. (2018) and Brüderl et al. (1992) found that the highest entrepreneurial success rates come from middle-aged founders (i.e., 30-40 years). Moreover, Wacth et al. (2016) state that women entrepreneurs who are older tend to bring more experience and knowledge to their small businesses, and in this way may influence outcomes. Older women entrepreneurs may also be more experienced in managing people and dealing with a wide variety of situations.

\section{Marital status}

Husband's role impacts the marriage; as such, resulting marital adjustments influence the wife and her business. Nikita et al. (2015) found that a spouse's influence has an essential effect on women entrepreneurs' productivity, as either the husband or the wife can hold a joint utility function driven by their relative productivity, which has been accumulated through experience and training (usually on the job). In fact, it is one of the primary determinants of productivity; according to (McElwee \& AlRiyami, 2003), their husbands influence them in starting a business, managing business, and coping with the demand to get financial assistant. Thus, marriage is hypothesized to have a positive effect on entrepreneurial outcomes.

\section{Number of children}

The presence of children increased women motivation to be entrepreneurs rather than men (DeMartino \& Barbat, 2003). Parental demand is assessed in terms of the number of children and their ages. Especially in rural areas, according to Tambunan (2017), the more children a woman has, in general, the greater the demand is for them to undertake the traditional role of being responsible for housework and childcare. Moreover, research by (Craig, 2006) shows that the experience of parenting as a mother is not the same as parenting as father, the condition of child care appear to be harder for mothers: mothering involves more double activity, more physical labor, a more rigid time table, and more overall responsibility than fathering. All these reasons drive women entrepreneurs to start their own businesses so that they can achieve work-life balance and give them flexibility, control and freedom to juggle with their family and social responsibilities (Roomi, 2012).

The similar research done by Ozcan (2011) reports that the presence of children might lead women to enter into a type of self-employment that requires fewer resources and accumulated skills; and furthermore, Buttner \& Moor (1997) state that the number of children motivates women entrepreneurs to measure success in terms of self-fulfillment and social contributions. This impact seems to specifically relate to the number of children they have: women with one child have a productivity rate $4.5 \%$ lower than women without children; this figure for women with two children increases to about 10\%, and reaches approximately $22 \%$ for women with three or more children (Mari et al., 2014).

Outcomes of women entrepreneurs

Cejka \& Eagly (1999) studied social role theory and considered the structural account of gender-based differences in human behavior; they assert that women and men behave according to the stereotypes associated with the social roles they occupy. Eagly \& Wood (1999) note that women are considered more communal, and this is characterized by attributes commonly associated with domestic activities (e.g., nurturance, connectedness, kindness, and emotional expressiveness). Likewise, McGowan et al. (2012) state that the key motivation for women in entering entrepreneurship is not making money: non-economic factors proved more important. Women have pointed to a greater sense of well-being, personal fulfillment, satisfaction, and joy in their various accomplishments in running their own businesses. Additionally, Bruni et al. (2004) state that women entrepreneurs socialize themselves into gender models and tend to embody values to produce behaviors that create a social expectation of behavior differences; this expectation bases itself on essentialist or culturalist assumptions and shapes a new normative model of women's experiences. Thus, it seems that non-economic indicators are stronger motivators. The non-economic outcomes of entrepreneurship, according to Wacht et al. (2016), include social impact (SI|) [which includes firm reputation and firm continuity (i.e., social responsibility among employees, firm-level social contribution, and the building of environmentally friendly firms)] and personal fulfilment (PF) [which encompasses personal aspects of success (i.e., worklife balance, personal work flexibility, autonomy in decisionmaking, and personal development)]. These collectively suggest considerable heterogeneity in the motivations of 
women entrepreneurs, ranging from self-realization, family security, and employee relations to societal contributions.

\section{Community impact}

"Community impact" refers to the positive image of a firm as a contributor to its community. Women entrepreneurship contributes significantly to job creation in developed and developing nations, and as Shmiln (2017) reports, many women want to contribute to society; and also, as Schneider (2017) suggests that women entrepreneurs have shown enhancement of social relationships, public visibility, and contributions to society. These study findings align with those of Bird \& Brush (2002), that women entrepreneurs satisfied with their entrepreneurial careers tend to focus more on socioemotional satisfaction stemming from interpersonal relationships with employees and customers, and their pursuit of social goals.

\section{Personal fulfillment}

PF encompasses personal aspects of success. Based on Bruni et al. (2004), women entrepreneurs' concerns vis-àvis relational aspects and flexibility are seen in so many supporting roles, and in their everyday coordination of family and work responsibilities; these matters are presented in the business literature as valuable and exploitable organizational resources. Shmiln (2017) offers another description of the outcomes of women entrepreneurs': in Asia, over $66 \%$ of women entrepreneurs cite the desire to have autonomy and freedom as their key reason for starting a business, followed by a sense of security and a sense of achieving goals. These include the desire for independence, being their own boss, achieving personal dreams, using their creative skills, being more fulfilled, and achieving a greater sense of power. McGowan et al. (2012) suggests also that they are motivated by time-use flexibility and childcare obligations.

Barriers as moderator between demographic characteristics and non-economics outcomes

Bougerre (2005) argues that women have a tendency to be discouraged from embracing entrepreneurial activities, especially when they face a number of constraints (e.g., lack of training, financing, gender inequality, and support for entrepreneurship, along with cultural and tradition-based constraints); this tendency influences the choices that they make and the actions executed in their businesses. The current study, therefore, analyzes whether certain barriers affect the relationship between the demographic characteristics and outcomes of women entrepreneurs. Thus there, are two variables; independent variables (age, marital status, and number of children) and its dependent variables [non-economic entrepreneurial outcomes (i.e., $\mathrm{Cl}$ and PF)]. In this subsection, we determine whether the following barriers (Akehurst, 2012) as on Table 1. moderate these relationships.

Table 1. Cross-references of the barriers to women entrepreneurs.

\begin{tabular}{l|l}
\hline Barriers & \multicolumn{1}{l}{ Description } \\
\hline (1) Infrastructure/trainings difficulties & \multicolumn{2}{l}{$\begin{array}{l}\text { Lack of training } \\
\text { lack of infrastructure and lack of transport facility. } \\
\text { Insufficient guidelines on the entrepreneurship activity . } \\
\text { Flexible job that allows them to combine their working lives } \\
\text { with the needs of their families and domestic work. } \\
\text { Role model and development of preference for an } \\
\text { entrepreneurial career. }\end{array}$} \\
\hline
\end{tabular}

(2) Difficulties due to gender

Further explained by that gender-related personal problems amplify obstacles for women entrepreneurs,

increase their perception of the negative influence on running their businesses.

\footnotetext{
(3) Bureaucratic and external financial difficulties
}

Furthermore, tax policy and taxation can have a profound

negative influence on the women entrepreneurship development.

Financial problems faced were non-availability of long-term

finance, the regular need of working capital.

Thus women also more likely to use loans from family members for their business.

\begin{tabular}{l|l}
\hline \multicolumn{1}{l}{ (4) Competition difficulties } & \multicolumn{1}{l}{$\begin{array}{l}\text { Success factors may be partially } \\
\text { determined by the competitive level of the market. }\end{array}$} \\
\hline (5) Conciliation difficulties & $\begin{array}{l}\text { That male entrepreneurs do not have to be anxious because } \\
\text { much about their household duties are done by the female } \\
\text { entrepreneurs. } \\
\text { That male entrepreneurs do not have to be anxious because } \\
\text { much about their household duties are done by the female } \\
\text { entrepreneurs; thus family moral support was associated } \\
\text { with a better women's firm performance. }\end{array}$ \\
\hline
\end{tabular}




\section{METHODS}

Based on literature reviewed, the model to explore whether the demographic characteristics of women entrepreneurs correlate significantly with the non-economic outcomes, and which barriers that moderate the relationship between the demographic characteristics and non-economic outcomes of women entrepreneurs in the rural areas of developing countries. See figure 1.

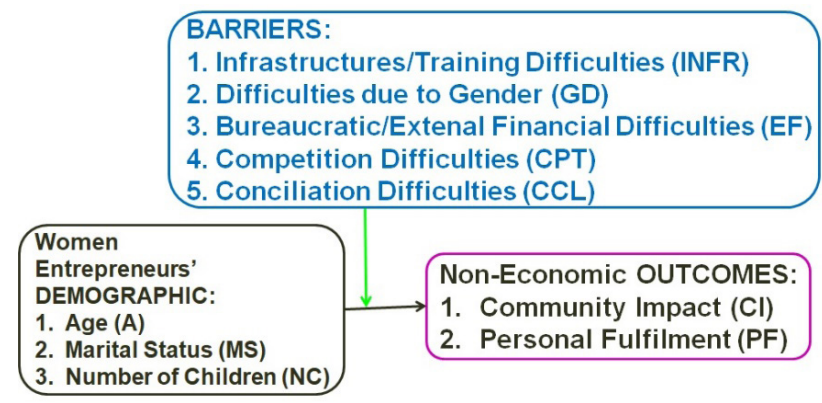

Figure 1. Research framework.

The study was conducted by interviewing women entrepreneurs in three subdistricts of Bantul, Indonesia, and a random sampling technique was adopted to select individuals from the study area. Bantul was chosen because it is a representative and appropriate rural Indonesian coastal area to study. The small businesses examined in the current study were those that deal in seafood warong, fresh fish retail, and fish snacks retail. A well-structured interview schedule was followed to collect primary data by survey. In accordance with this goal, interviews were conducted with women entrepreneurs in Sanden, Srandakan, and Kretek. The sample comprised of 30 women entrepreneurs from each of these three subdistricts. Bantul was chosen because it contains many women entrepreneurs and is therefore a representative and appropriate rural Indonesian coastal area to study. In all, 90 women entrepreneurs in the coastal area were surveyed, and the responses of 79 of them were considered complete and valid, and then analyzed using structural equation modeling (i.e., partial least squares). Data were obtained from the sample of women entrepreneurs that are representative of small enterprises. [Note that for definition purposes, a "small enterprise" is-as per the Regulation of the Minister of Industry, Indonesia-an enterprise that employs a maximum of 19 laborers and has an investment value of less than IDR 1,000,000,000, excluding the business's land and premise.] Details of demographic characteristics of sample are given at Table 1.

After had the partial least squares results, then moderation test to be used to received varying degrees of support. Moderation test are based on Jeremy Dawson Slopes to plot the interaction effects which help interpret two-way interaction effects (often thought of as a relationship between an independent variable (i.e. demographic characteristics) and dependent variable (i.e. non-economic outcomes), moderated by a third variable (i.e. barriers)), first run a regression analysis, including both independent variables (referred to hence as the demographic characteristics and barriers) and their interaction (product) term (Dawson, 2014).

\section{RESULTS AND DISCUSSION}

Results

Table 1. Descriptive summary.

\begin{tabular}{|c|c|c|c|}
\hline Demographic Characteristic & Frequency & Percentage & Cumulative \\
\hline Age: less than 30 year & 4 & 5.06 & 5.06 \\
\hline Age: between 31 and 39 year & 25 & 31.65 & 36.71 \\
\hline Age: between 41 and 49 year & 29 & 36.71 & 73.42 \\
\hline Age: between 51 and 59 & 18 & 22.79 & 96.20 \\
\hline Age: between 61 and 67 & 3 & 3.80 & 100.00 \\
\hline Marital Status: Married & 70 & 88.61 & 88.61 \\
\hline Marital Status: Widowed & 9 & 11.39 & 100.00 \\
\hline Number of Children: 1 & 16 & 20.25 & 20.25 \\
\hline Number of Children: 2 & 42 & 53.16 & 73.42 \\
\hline Number of Children: more than 2 & 21 & 26.53 & 100.00 \\
\hline
\end{tabular}

Table 1 shows that majority women entrepreneurs are between 31 to 49 of age, and most of them are married with 2 children. They are experienced women on being entrepreneurs in seafood warong to earn more financial support for their children needs and family expenses. Those whose age are 51 and above are more experience to continue their business for pleasure and leisure. Meanwhile those who are less than 30 years old are to continue their mother's business.

Tabel 2 for validity and reliability results indicate that the models are stable. Also the results demonstrate all the demographic characteristics of women entrepreneurs (i.e., age, marital status, and number of children). It correlates significantly with two sets of non-economic outcomes: the first two of these demographic characteristics have positive relationships, while the third has a negative relationship. Overall, as in Figure 2, given that significant ( $a=0.05$ (twotailed test)) main model of these variables was found in all of the relationships between the demographic characteristics of women entrepreneurs (age, marital status, and number of children) and their non-economic outcomes ( $\mathrm{Cl}$ and $\mathrm{PF})$. 
Table 2. Validity and reliability result

\begin{tabular}{l|lll|l|l}
\hline Noneconomic Outcomes & Cronbach's Alpha & \multicolumn{1}{l}{$\begin{array}{l}\text { Composite } \\
\text { Reliability }\end{array}$} & $\begin{array}{l}\text { Average Variance } \\
\text { Extracted }\end{array}$ & $\mathbf{R}^{2}$ & \multicolumn{1}{l}{$\begin{array}{l}\mathbf{R}^{2} \\
\text { Adjusted }\end{array}$} \\
\hline Community Impact & 0.794 & 0.879 & 0.707 & 0.429 & 0.406 \\
\hline Personal Fulfilment & 0.770 & 0.848 & 0.583 & 0.411 & 0.387 \\
\hline
\end{tabular}

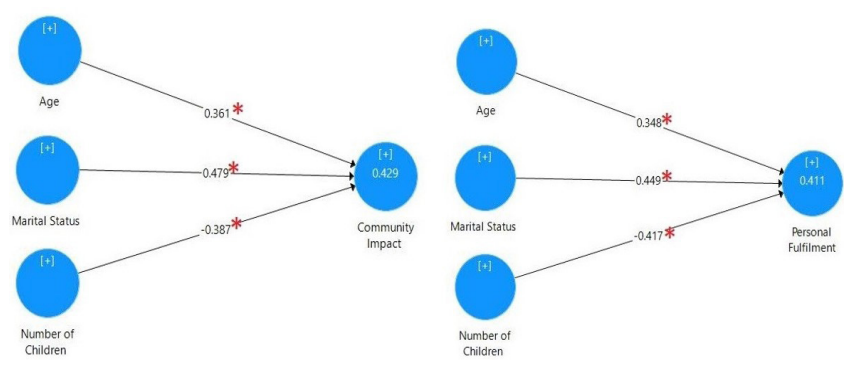

Figure 2. Outer model estimation of the relationship between demographic characteristics and non-economic outcomes.

The main implications of the two results derived from the main model are that being aged, married, and having fewer children seems to bring about better non-economic outcomes among women entrepreneurs, at least in the context of running small businesses in the rural coastal area of Bantul, Indonesia. These results suggest that some relationships go beyond the specific developing socioeconomic context in which this research was conducted and instead are grounded on some common characteristics in rural coastal Indonesia. Such characteristics, it can be said, increase the noneconomic outcomes of women entrepreneurs. For example, being older means one has acquired more experience and might obtain more financial stability - which can, in turn relate to higher PF (i.e., they can rely on their own business decision-making, as having more experience is likely to lead to sounder decision-making) and higher $\mathrm{Cl}$ (i.e., as women entrepreneurs age, they tend to devote more time and labor to their community). Similarly, by being married, women entrepreneurs can enjoy the support of their husband and his family, and this can lead to higher PF (i.e., they can rely on their husband to share in parenthood duties, and this provides them with more flexibility in how much time they spend in the home versus at the business premises). Being married can also lead to higher $\mathrm{Cl}$ (i.e., they are able to focus adequately on having a good relationship with their employees). However, the more children a woman has, the less time she can devote to her business. As a result, she will have less personal satisfaction, as she will feel she does not have sufficient work-life balance between time spent on motherhood and her business (PF); she will also have less time to devote to community sharing at her business premises $(\mathrm{Cl})$.

This study also focused especially on the moderation of five barriers [i.e., infrastructure/training, gender, bureaucratic/ financial, competition, and conciliation difficulties; based on Akehurst et al. (2012)]. These barriers are likely to affect the relationship between the demographic characteristics and non-economic outcomes of women entrepreneurs. The basic idea in anticipating such moderation is that we may expect a weaker relationship between age and noneconomic outcomes among women entrepreneurs who face high-level barriers than among those who face lowlevel barriers.
According to these results, our moderation test hypotheses received varying degrees of support. Overall, given that only 5 of the 30 moderation relationships that were tested about the relationship between demographic characteristics and both types of noneconomic outcomes were statistically significant at the 0.05 level (two-way test), our results suggest that women entrepreneurs are influenced more by conciliation difficulties. Conciliation difficulties significantly moderate the relationship between age and both types of noneconomic outcomes and also the relationship between number of children and $\mathrm{Cl}$, followed by significant moderation of infrastructure/training difficulties in the relationship between age and PF, and also significant moderation of bureaucratic/external financial difficulties in the relationship between age and PF.

\section{Discussion}

Based on the aforementioned results, we hypothesized as to whether the five cited barriers would moderate the relationship between the demographic characteristics and outcomes of women entrepreneurs, such that this relationship would be adversely affected when the barriers are higher (i.e., the moderation test hypotheses). Overall, the results regarding the moderation test hypotheses suggest that women entrepreneurs are influenced more by conciliation difficulties than by other barriers in the relationship between demographic characteristics and outcomes; meanwhile, none of the moderation test results indicate there is no influence on the relationship between marital status and the outcomes of women entrepreneurs.

The following Figures 3-7 show that higher barriers can attenuate the magnitude of the relationship between demographic characteristics (age and number of children) and both sets of outcomes (Cl and PF).

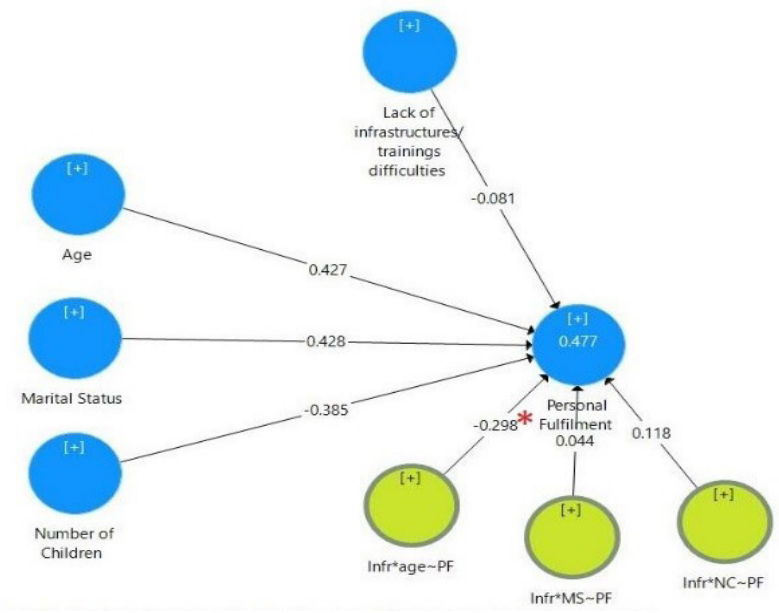

Figure 3a. Model estimation of moderation test of infrastructure/trainings difficulties between age and personal fulfilment.

Note: *=s significant at $\alpha=0.05$ two-tailed test. 


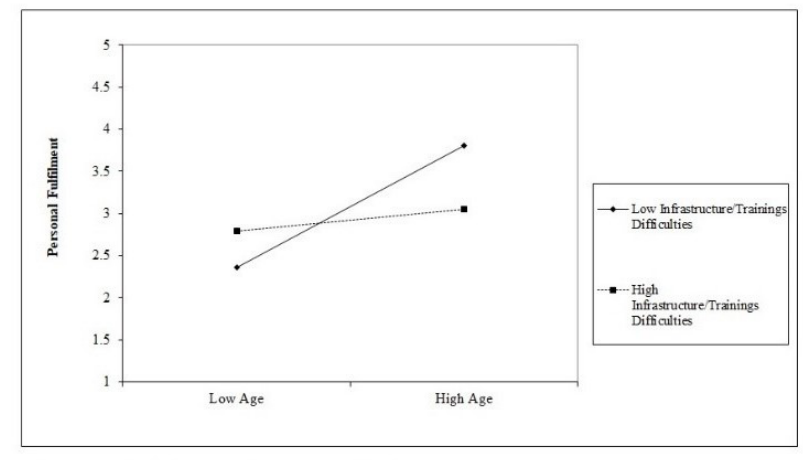

Figure 3b. Moderation test of infrastructure trainings difficulties that moderates relationship between age and personal fulfillment.

A possible explanation for the results presented in Figure 3 is that when infrastructure/training-related difficulties are in low-level, older women entrepreneurs can enjoy developing and utilizing their relatively more abundant resources and capabilities more effectively. (Such difficulties can relate to the availability of sufficient business managerial training from the government or a related institution; the provision of proper transport facilities, and of related business information and guidance; the availability of role models of successful women entrepreneurs; and the occurrence of fewer problems in combining family life and business activities). As a result, older women have a greater internal locus of control, which in turn leads to higher PF. Indeed, the gap in PF between young and older women entrepreneurs is quite wide. Meanwhile, when the difficulties are sufficiently serious (e.g., a lack of business managerial training, a lack of related information and guidance, and a lack of role models), older women entrepreneurs cannot develop and utilize their resources and capabilities to their full potential. Consequently, the gap in personal performance between young and older women entrepreneurs is likely to be narrow. Young women entrepreneurs also suffer from these barriers, but to a lesser degree, because their maximum potential is lower than that of older women entrepreneurs; therefore, one could say that any infrastructure/training difficulties that women entrepreneurs in developing countries, face will adversely affect the relationship between the age of women entrepreneurs and their PF. These findings support that infrastructure/training difficulties negatively moderate the relationship between age and PF, so that the relationship is adversely affected.

Figure 4 shows that when the bureaucratic/external financial difficulties are in low-level (e.g., legislation and bureaucracy are relatively easy to access, fiscal duties and obligations are small and easy to fulfill, and there is easy access to financial support from formal institutions), older women entrepreneurs can develop and utilize their relatively larger resources and capabilities more effectively. As a result, they will acquire a greater internal locus of control, which in turn allows them to pay more attention to attaining greater PF. The gap in PF between young and older women entrepreneurs is relatively wide. Meanwhile, when the difficulties are seriously high (e.g., lack of financial support from government and other formal financial institutions), older women entrepreneurs cannot develop and utilize their resources and capabilities to their full potential; consequently, in such cases, the gap in personal performance between young and older women entrepreneurs will likely be narrow. Young women entrepreneurs also suffered from these barriers, but to a lesser degree-again, because their maximum potential is relatively lower than that of older women entrepreneurs. Therefore, one can conclude that the bureaucratic/ external financial difficulties that women entrepreneurs in developing countries, face can adversely affect the relationship between the age of women entrepreneurs and their PF. These findings also support that Bureaucratic/ external financial difficulties negatively moderate the relationship between age and $\mathrm{PF}$, so that the relationship is adversely affected.

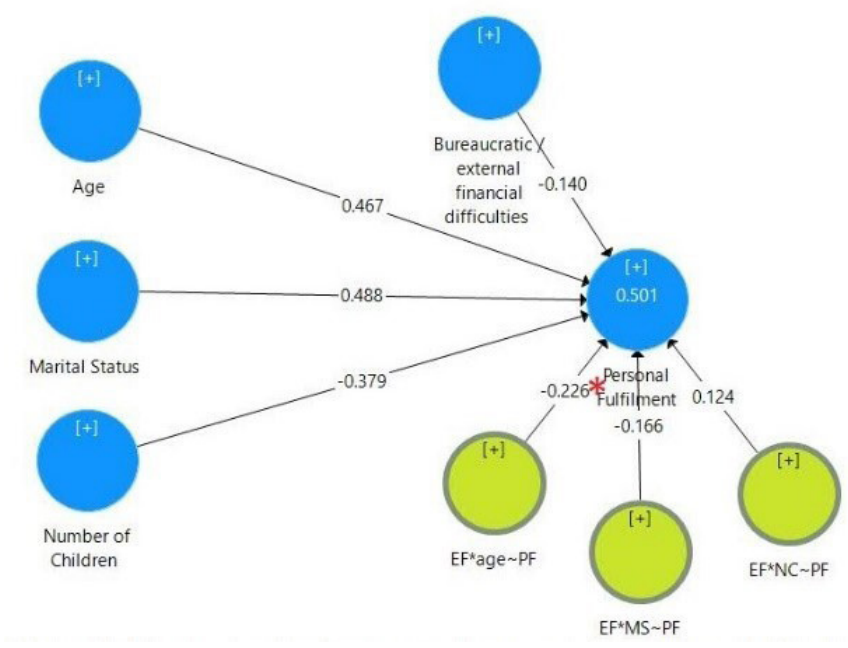

Figure 4a. Model estimation of moderation test of bureaucratic/external financial difficulties between age and personal fulfilment.

Note: * significant at $\alpha=0.05$ two-tailed test.

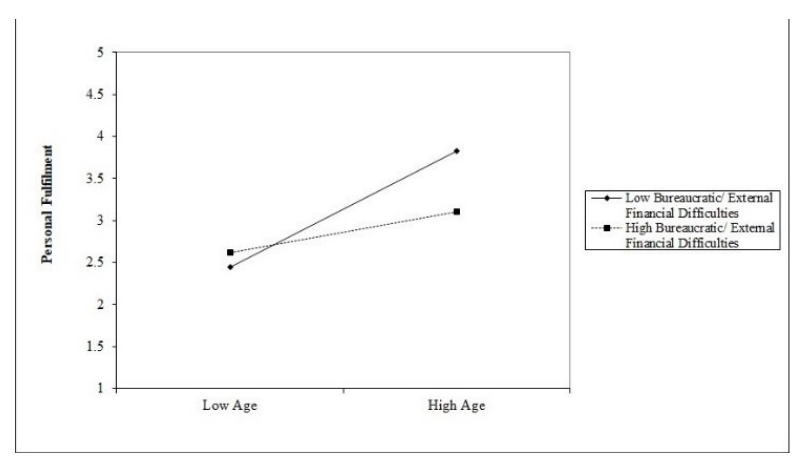

Figure 4b. Moderation test of bureaucratic/external financial difficulties that moderates relationship between age and personal fulfillment. 


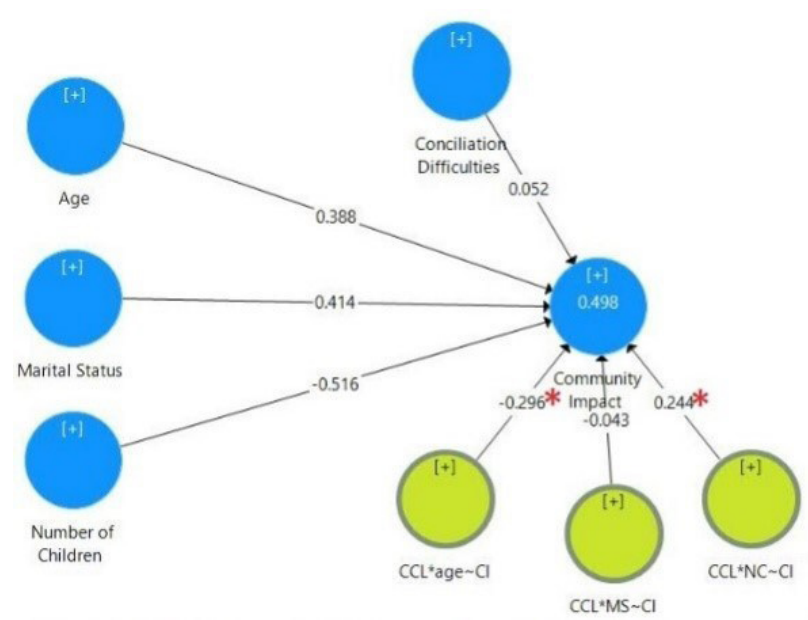

Figure 5a. Model estimation of moderation test of conciliation difficulties between age and community impact.

Note: * significant at $\alpha=0.05$ two-tailed test.

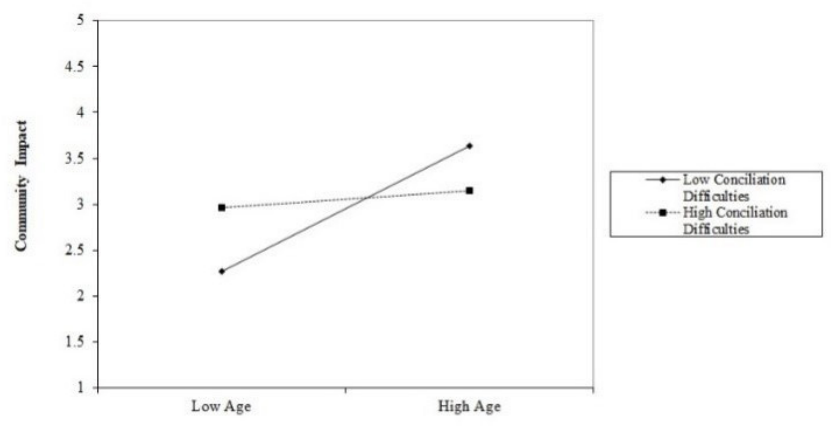

Figure 5b. Moderation test of conciliation difficulties that moderates relationship between age and community impact.

Figure 5 shows that when the conciliation difficulties are low, older women entrepreneurs can pay more attention to social sharing, as they can better manage their time and employee resources and run their business effectively-and thus share more business benefits with their community. (With conciliation at home, women entrepreneurs and their husband have a mutual understanding vis-à-vis spending equitable amounts of time and attention on business and family matters; with conciliation on the business premises, women entrepreneurs and their employees have a mutual understanding vis-à-vis managing employees and providing time off from work for personal reasons.) Thus, the gap in $\mathrm{Cl}$ between young and older women entrepreneurs is relatively wide. Meanwhile, when conciliation difficulties are seriously high (e.g., time spent on domestic duties is much higher relative to that of their husband, and employee turnover is relatively high), older women entrepreneurs focus more on their economic goals in order to continue running their business, and thus pay less attention to noneconomic goals (e.g., they share less time and spend fewer resources on their surrounding community). Consequently, the gap in $\mathrm{Cl}$ between young and older women entrepreneurs is likely to be narrow. Again, young women entrepreneurs are also afflicted by these barriers, but their maximum potential is relatively lower, as is their $\mathrm{Cl}$. Therefore, one can conclude that conciliation difficulties that women entrepreneurs in developing countries, face can adversely affect the relationship between the age of women entrepreneurs and their $\mathrm{Cl}$.

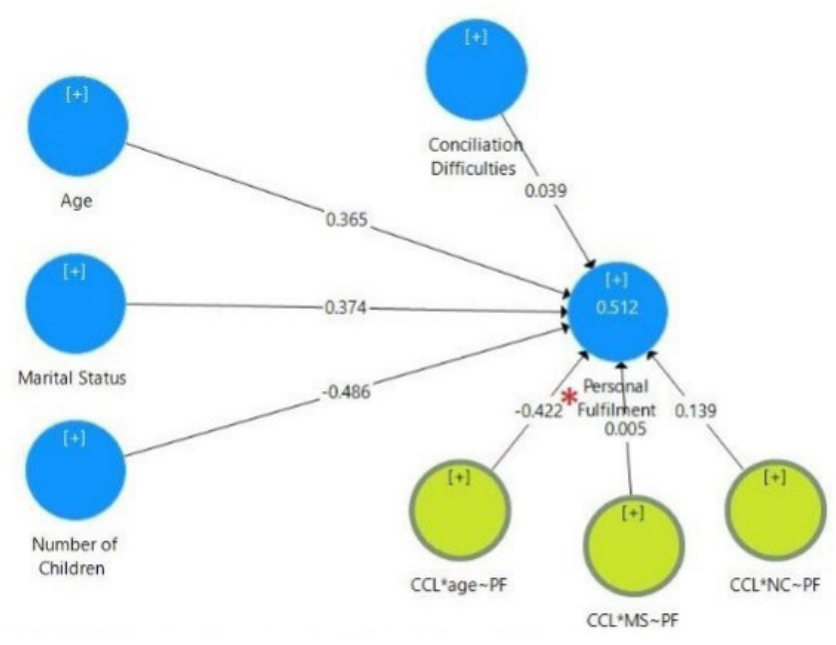

Figure 6a. Model estimation of moderation test of conciliation difficulties between age and personal fulfillment.

Note: * significant at $\alpha=0.05$ two-tailed test.

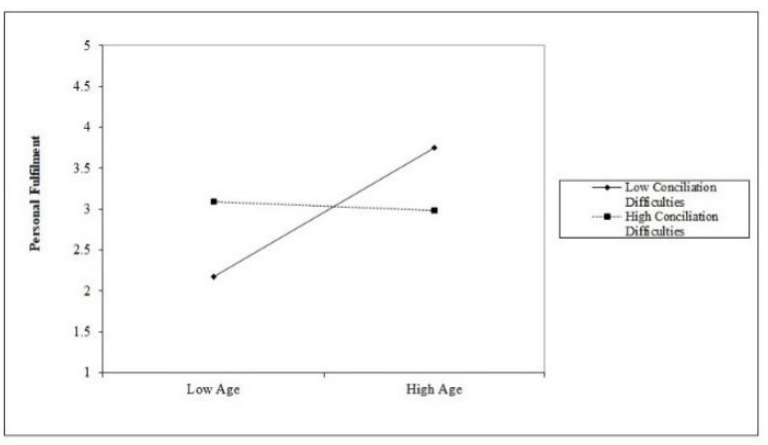

Figure 6b. Moderation test of conciliation difficulties that moderates relationship between age and personal fulfillment.

Figure 6 shows that when conciliation difficulties are in low-level, older women entrepreneurs pay more attention to their PF, aside from their community involvement, by exploring their potential more and deriving some individual satisfaction from having greater work-life balance; they also acquire a sense of personal development from having a successful business. (In such cases, women entrepreneurs and their husband equitably share time and resources in family matters, and in business, women entrepreneurs manage their employees effectively so that their business runs well.) Thus, the gap in PF between young and old women entrepreneurs is relatively wide. Meanwhile, when such difficulties are seriously high (e.g., their time spent on domestic duties is much higher than that of their husband, and employee turnover is relatively high), older women entrepreneurs focus more on their economic goals in order to continue running their business and become more financially secure; in the process, they pay less attention to noneconomic goals-that is, they tend to sacrifice their personal satisfaction (e.g., spend more time at their business premises once they have free time in their household). Consequently, the gap in personal performance between young and old women 
entrepreneurs is likely to be narrow. As before, young women entrepreneurs are also afflicted by these barriersalbeit to a lesser degree, because their maximum potential is lower than that of their older counterparts, and so their $\mathrm{PF}$ is also relatively lower. Therefore, one can conclude that the conciliation difficulties that women entrepreneurs in developing countries face can adversely affect the relationship between the age of women entrepreneurs and their PF.

An interesting result, as presented in Figure 5b, is that older women entrepreneurs are likely to be afflicted a little more by enhanced conciliation difficulties, compared to their younger counterparts. Family matters seem to be crucial to women entrepreneurs, especially in comparison to PF performance, particularly when they are compelled to spend more time looking after their family than their husband does. (The traditional model of work division within the family unit stipulates that domestic work and eldercare are assigned predominantly to women, and given that the parents, parents-in-law, and husbands of younger women are not as likely to require eldercare, this expectation will impact older women entrepreneurs relatively more.)

Figure 7 shows that when the conciliation difficulties are low (e.g., women entrepreneurs and their husbands can easily coordinate child rearing, and women entrepreneurs are able to actively run their business without fully relying on their employees to do so), women entrepreneurs with more children pay less attention to their $\mathrm{Cl}$, as they spend more time on their motherhood responsibilities. Thus, the gap in $\mathrm{Cl}$ between women entrepreneurs with fewer children and those with more children is relatively wide. Meanwhile, when such difficulties are seriously high (e.g., women entrepreneurs cannot rely much on their husband to care for children while they run their business), women entrepreneurs with more children will pay more attention to their motherhood responsibilities and less attention to their business; as a result, they will also pay less attention to their community and environment (e.g., devote a smaller share of their time to the community and to being an environmentally friendly firm). Consequently, the gap in $\mathrm{Cl}$ performance between women entrepreneurs with fewer and more children is likely to be narrow. Women entrepreneurs with fewer children are afflicted by these same challenges, albeit to a lesser degree; therefore, one can conclude that the conciliation difficulties that women entrepreneurs in developing countries, face can adversely affect the relationship between the number of children and $\mathrm{Cl}$. This finding aligns with that of Parasuraman and Simmers (2001), that women are more likely than men to have domestic responsibilities. This situation may cause difficulties for women in balancing their business and family lives. As seen elsewhere worldwide, a lack of family support systems can hinder the development of women entrepreneurs and their businesses. This final set of findings supports that conciliation difficulties positively moderate the relationship between a larger number of children and $\mathrm{Cl}$, so that the relationship is adversely affected.

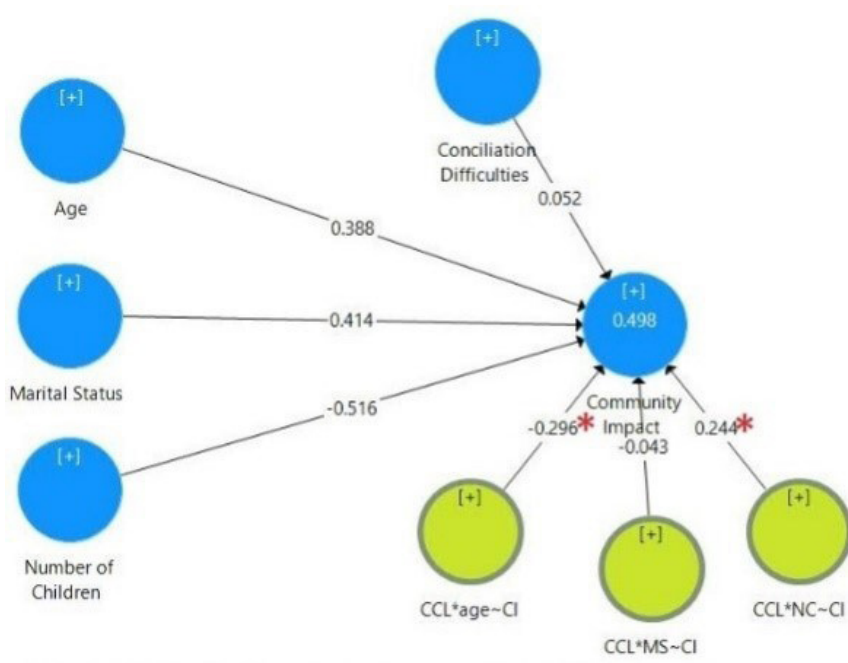

Figure 7a. Model estimation of moderation test of conciliation difficulties between number of children and community impact.

\section{Note: * significant at $\alpha=0.05$ two-tailed test}

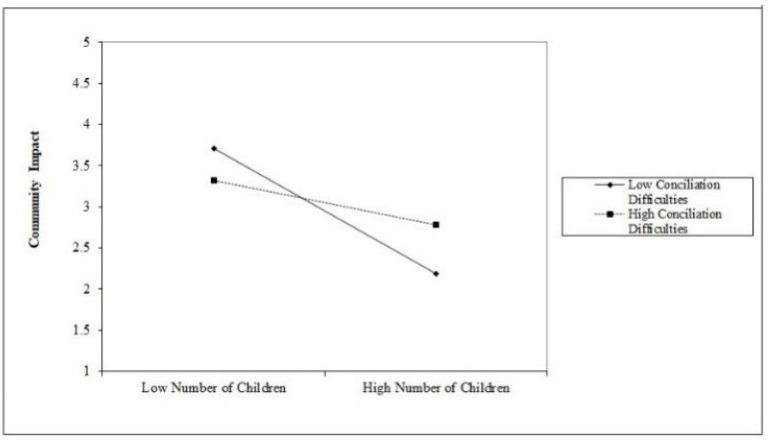

Figure 7b. Moderation test of conciliation difficulties that moderates relationship between number of children and community impact.

Meanwhile, for marital status, we found there to be no barriers that might moderate the relationship between marital status and the outcomes of women entrepreneurs. This means that for women entrepreneurs, the aforementioned barriers may have no bearing on the relationship between marital status and either $\mathrm{Cl}$ or PF outcomes. Regardless of the magnitude of the barriers, the relationship between marital status and both sets of outcomes remain approximately the same.

\section{CONCLUDING REMARKS}

The conclusions of this study are as follows. First, there is a relationship between age and better community impact $(\mathrm{Cl})$ and better personal fulfillment (PF)]; second, there is a relationship between being widowed and having worse $\mathrm{Cl}$ and PF; third, there is a relationship between having larger number of children and worse $\mathrm{Cl}$ and PF.

The follows conclusion regarding moderation, fourth, infrastructure/training difficulties negatively moderate the relationship between age and PF, it means when the difficulties are sufficiently serious, the gap in personal performance between young and older women 
entrepreneurs is likely to be narrower compare to when the difficulties are in low-level. Fifth, bureaucratic/external financial difficulties negatively moderate the relationship between age and PF, it means when the difficulties are seriously high, the gap in personal performance between young and older women entrepreneurs will likely be narrower than when the difficulties are in low-level. Sixth, conciliation difficulties negatively moderate the relationship between age and both sets of outcomes $(\mathrm{Cl}$ and PF), when conciliation difficulties are seriously high, the gap in community impact and personal performance between young and old women entrepreneurs is likely to be narrower compare to when the difficulties are in lowlevel. Young women entrepreneurs also suffered from these three barriers (infrastructure/training, bureaucratic/ external financial, and conciliation difficulties), but to a lesser degree-again, because their maximum potential is relatively lower than that of older women entrepreneurs. Finally, conciliation difficulties positively moderate the relationship between a larger number of children and $\mathrm{Cl}$, when such difficulties are seriously high, the gap in $\mathrm{Cl}$ performance between women entrepreneurs with fewer and more children is likely to be narrower than when the difficulties are in low-level. Women entrepreneurs with fewer children are afflicted by these same challenges, albeit to a lesser degree.

Policy implications can be formulated on the basis of the findings are as follows. Governments should pay more attention to establishing and funding programs that offer more support to women entrepreneurs, such as those pertaining to financial assistance, organizational help, business and entrepreneurial skill training, mentoring from role models and successful entrepreneurs, information/guidance from related agencies regarding entrepreneurship, and opportunities to directly observe successful businesses. Additionally, more developed economies should focus more on providing effective help to women entrepreneurs, and on offering programs that will teach them strategies by which to cope with personal problems and other obstacles.

However, as there were limitations of this study, for future research it is suggested it is important to involve an inter-regional comparison of coastal areas. Also, a complementary line of research could include an analysis of an environment where women embark on their careers, and how that environment may serve as a conditioning factor of entrepreneurial potential. Additionally, as this study focused solely on women entrepreneurs in a developing rural area, and future comparative studies should examine both developing and undeveloped rural areas, to further investigate demographic characteristics and how they impinge upon noneconomic outcomes. Such future research should examine the various barriers that women entrepreneurs face, in tandem with a consideration of geographical characteristics (e.g., rural areas and local community characteristics in Indonesia), and examine how those women entrepreneurs deal with such barriers.

\section{REFERENCES}

Acs, Z.J., P. Arenius, M. Hay \& M. Minniti. 2004. Global entrepreneurship monitor 2004 Executive Report. London: Babson College and London Business School
Akehurst, G., E. Simarro \& A. Mas-Tur. 2012. Women Entrepreneurship in Small Service Firms: Motivations, Barriers, and Performance. The Service Industries Journal. 32 (15) : 2489-2505

Alfonso, C. 2010. "And l'd like to thank my wife...': Gender dynamic and the etnic 'family business'. Australian Faminist Studies, 8 (17) : 93-108

Azoulay, P., B. Jones, J.D. Kim \& J. Miranda. 2018. Age and high-growth entrepreneurship. Working Paper Series

Baines, S \& J. Wheelock. 1998. Working for each other, the household and micro-business survival and growth. International Small Business Journal. 17 (1) : 16-35

Bass, B.M., B.J. Avolio \& L. Atwater .1996. The transformational and transactional leadership of men and women. Applied Psychology: An International Review. 45 (1) : 5-34

Benzing, C., H.M. Chu \& O. Kara. 2009. Entrepreneurs in Turkey: A factor analysis of motivations, success factors, and problems. Journal of Small Business Management. 55-91

Bergmann, H \& R. Sternberg. 2007. The changing face of entrepreneurship in germany. Small Business Economics. 28 : 205-221

Bird, B. 1989. Entrepreneurial Behavioral. Glenview. II: Scott, Foresman and Company

Bird, B \& C. Brush. 2002. A gendered perspective on organizational creation. Entrepreneurship theory and practice. Entrepreneurship Theory and Practice. $26: 41-65$

Bosma, N \& R. Harding. 2007. Global Entrepreneurship: GEM 2006 Summary Results. Babson College and London Business School, London U.K., and Babson Park, M.A.

Bosma, N., M.V. Praag \& G.D. Wit. 2000. Determinants of Successful Entrepreneurship SCALES. Ministry of Economic Affairs, Netherlands: Research Report 0002/E.

Bougerre, N. 2005. An Investigation of Women Entrepreneurship: Motives and Barriers to Business Start Up in the Arab World. Journal of Women's Entrepreneurship and Education. 1 (2) : 86-104

Brüderl, J., P. Preisendörfer \& R. Ziegler. 1992. Survival chances of newly founded business organizations. American sociological review. 57: 227-242

Bruni, A., S. Grerardi \& B. Poggio. 2004. Entrepreneurmentality, Gender, and the Study of Women Entrepreneurs. Journal of Organizational Change Management. 17 (3) 256-268

Burke, S \& K.M. Collins. 2001. Gender Differences in Leadership Styles and Management Skills. Women in Management Review. 16 : 244-256

Buttner, E.H. 2001. Examining Female Entrepreneurs' Management Style: An Application of a Relational Frame. Journal of Business Ethics. 29 : 253-269

Buttner, E. H \& D.P. Moor. 1997. Women's organizational exodus to entrepreneurship_self-reported motivations and correlates with success. J SMALL BUS MANAG 
Cejka, M. A \& .H. AEagly. 1999. Gender-stereotypic images of occupations correspond to sex segregation of employment. Personality and Social Psychology Bulletin. 25 (4) : 413-423

Chin. 1998. The partial least squares approach for structural equation modeling. In G. A. Marcoulides (Ed.), Modern methods for business research. 295336

Chin, W.W. 2010. Bootstrap Cross-Validation Indices for PLS Path Model Assessment. In V. E. Vinzi, W. W. Chin, J. Henseler, \& H. Wang, Handbook Partial Least Squares. Concepts, Methods and Applications. Singapore: Springer. 83-98

Chin, W \& R.P. Newsted. 1999. Structural Equation Modeling Analysis with Small Samples Using Partial Least Square. Statistical Strategies for Small Sample Research. In R. H. Hoyle, Statistical Strategies for Small Sample Research. Houston: Sage Publication. 307-341

Craig, L. 2006. Does father care mean fathers share? A comparison of how mothers and fathers in intact families spend time with children. Gender \& Society. 259-281

Dawson, J. 2014. Moderation in management research: What, why, when and how. Journal of Business and Psychology. 29:1-19

DeMartino, R \& R. Barbat. 2003. Differences between women and men MBA entrepreneurs: exploring family flexibility and wealth creation as career motivators. Journal of Business Venturing. 815832

Derera, E., P. Chitkunye, \& C. O'neill. 2014. The impact of gender on start-up capital: a case of women entrepreneurs in South Africa. The Journal of Entrepreneurship. 23 : 5-114

Duncan, G \& S. Hoffman. 1985. A reconsideration of the economic consequences of marital dissolution. Demography. 22 (4) : 485-497

Eagly, A. H \& W. Wood. 1999. The origins of sex differences in human behavior-Evolved dispositions versus social roles. American Psychologist. 54 (6) : 408-423

Hair, J. F., Hult, G.M., Ringle \& M. Sarstedt, M. 2016. A Primer on Partial. 2nd Ed. Thousand Oaks, CA : Sage

Halfacree, K. 2006. From dropping out to leading on? british countercultural back-to-the-land in a changing rurality. Progres in Human Geography. 30 (3) : 309366

Hasan, F.S \& M.M. Almubarak. 2016. Factors influencing women entrepreneurs' performance in SMEs. World Journal of Entrepreneurship, Management and Sustainable Development. 12 (2) : 82-101

Huarng, K., A. Mas-Tur \& T.H. Yu. 2012. Factors affectingthe success of women entrepreneurs. International Entrepreneurs Management Journal. 847-497

Idrus, S., Pauzi, N. M., \& Munir, Z. A. 2014. the effectiveness of training model for women entrepreneurship program. Procedia - Social and Behavioral Sciences. $129: 82-89$
Japhta, R., Y. Murthy, A. Marina \&A. Gupta, A. 2016. Womenowned SMEs in Indonesia: A Golden Opportunity for Local Financial Institutions. International Finance Coorporation (IFC) by the Frankfurt School of Finance and Management

Jennings, J \& M. McDougald. 2007. Work-family interface experiences and coping strategies: implications for entrepreneurship research and practice. Academy of Maagement Review. 32 : 747-760

Kuratko, D., F.S. Hornsby\& D.W. Naffzig. 1997. An examination of owner's goals in sustaining entrepreneurship. Journal of Small Business Management. 24-33

Levesque, M \& M. Minniti, M. 2006. The effect of aging on entrepreneurial behavior. Journal of Business Venturing. 21 (2) : 177-194

Loscocco, K \& J. Robinson. 1991. Barriers to women's small-business success in the United States. Gender and Society. 5 (4)

Manzanera-Roman, S \& G. Brandle, G. 2016. Abilities and skills as factors explaining the differences in women entrepreneurship,. Suma de Negocios. 7 (15) : 38-46

Mari, M., S. Poggessi \& L. de Vita. 2014. Italian women entrepreneurs: An empirical investigation. 28th Annual Conference of the British Academy of Management. Belfast: Research Gate.

Markantoni, M\& B. van Hoven. 2012. Bringing "Invinsible" side activity to light. A case study of female entrepreneurs in the Veenkolonien, the Netherlands. Journal of Rural Studies. 28 : 6507-516.

Marsden, T. 1999. Rural futures: The concumption countryside and its regulation. europan society for rural sociology. Sociologia Ruralis. 39(4)

McCracken, K., S. Marquez, C. Kwong, U. Stephan, A. Castagnoli \& M. Dlouha. 2015. Women's entrepreneurship: Closing the gender gap in access to financial and other services and in social entrepreneurship. Brussels: European Union

McElwee, G \& R. Al-Riyami. 2003. omenentrepreneursinOman:somebarriersto success. CareerDevelopment International. 339-346

McGowan, P., C.L. Redeker, S.Y. Cooper \& K. Greenan. 2012. Female Entrepreneurship and The Management of Business and Domestic Roles: Motivations, Expectations and Realities. Entrepreneurship \& Regional Development. 24 : 53-72

Meenakshi, M \& S. Mahapatra. 2015. Constraints Faced by Women Entrepreneurs. International Journal of Management. 6 (5) : 8-17

Meyer, N \& J. Landsberg. 2015. Motivational factors influencing women's entrepreneurship: A case study of female entrepreneurship in South Africa. International Journal of Economics and Management Engineering. 9 (11) : 3864-3869

Ming-Yen, W.T \& C. Siong-Choy. 2007. theorising a framework of factors influencing performance of women entrepreneurs in Malaysia. Journal of Asia Entrepreneurship and Sustainability. 3 (2) 
Minialai, C \& H. Sqalli. 2016. How to improve the governance of support for entrepreneurship initiatives. Youth and Entrepreneurship

Minniti, M. 2010. Female entrepreneuship and economic activity. European Journal of Development Research. 22 (3) : 294-312

Minniti, M \& P. Arenius. 2003. Women in entrepreneurship. The entrepreneurial advantage of nations. First Annual Global Entrepreneurship Symposium. New York: United Nations Headquarters

Moudud Ul-Huq, S. 2013. Women entrepreneurship development In Bangladesh challenges and prospects. International Journal of Innovative Research and Development. 41-48

Mwobobia, F.M. 2012. The challenges facing small-scale women entrepreneurs: A case of Kenya. International Journal of Business Administration. 3 (2)

Nayyar, P., A. Sharma, J. Kishtwaria \& Rana. 2007. Causes and constraints faced by women entrepreneurs in entrepreneurial process. Journal of Social Science. 14 (2): 99-102

Niehm, L.S., J. Swinney \& N.J. Miller. 2008. Community social responsibility and its consequences for family business performance. Journal of Small Business Management. 46 (3) : 331-350

Nikita, A., L.M. Shelton \& S.L. Loarne. 2015. An examination of how husbands, as key stackeholders, impact the success of women entrepreneurs. Journal of Small Business and Entreprise Development. 22 (1) : 38-62

Oberhauser, A.M. 2010. Gender and household economic strategies in rural appalachia. Gender, Place and Culture. 2 (1) : 51-70

Ozcan, B. 2011. Only the Lonely?: The Influence of Spuse on The Transition to Self-Employment. Small Business Economics. ISSN 1573-0913, Springer

Panda, S. 2018. Constraints faced by women entrepreneurs in developing countries: review and ranking. Gender in Management: An International Journal. 33 (4) : 315-331

Parasuraman, S \& C.A. Simmers. 2001. Type of employment, work-family conflict and well-being: A comparative study. Journal of Organizational Behavior. 22 (5) : 551-568

Pathak, S., S. Goltz \& M.W. Buche. 2013. Influences of gendered institutions on women's entry into entrepreneurship. International Journal of Entrepreneurial Behaviour \& Research. 19( 5) 478-502

Puskompublik. 2014. Berita Utama. Retrieved from Ministry of Tourism of the Republic of Indonesia: http://www. kemenpar.go.id/asp/detil.asp?c=16\&id $=2817$

Raposo, M., A. do Paco \&J. Ferreira, J. 2006. Entrepreneur's profile: a taxonomy of attributes and motivations of university students. Journal of Asia Entrepreneurship and Sustainability. 2 (2): 1-22

Real, J.C., J.L. Roldan \& A. Leal. 2014. From entrepreneurial orientation and learning orentation to business perfornamnce: Analysing the mediating role of organizational learning and the moderating effect of organizational size. British Journal of Management. $25: 128-208$
Renzulli, L.A., H. Aldrich\& M. James. 2000. Family matters: Gender, networks, and entrepreneurial outcomes. The University of North Carolina Press Social Forces. 79 (2) : 523-546

Roldán, J \& M.J. Sánchez-Franco. 2014. Variance-Based Structural Equation Modeling. In M. Mora, O. Gelman, A. Steenkamp, \& M. S. Raishinghani, Research Methodologies, Innovation and Philosophies in Software System Engineering and Information Systems (pp. 193-221). Mexico: IGI Global

Roomi, M.A. 2012. Gender and work-life balance: a phenomenological study of women entrepreneurs in Pakistan. Journal of Small Business and Enterprise Development. 19 : 209-228

Sadi, M.A \& B.M. Al-Ghazali. 2012. The dynamics of entrepreneurial motivation among women. Asian Academy of Management Journal. 17 (1) : 97-113

Scherer, R.F., J.S. Adams, S.S. Carley \& F.A. Wiebe. 1989. Role model performance effects on development of entrepreneurial career preference. Entrepreneurship Theory and Practice. 13 (3) 53-72

Schindehutte, M., M. Morris \& C. Brennan. 2003. Entrepreneurs and motherhood: Impacts on their children in South Africa and the United States. Journal of Small Business Management. 41 (1) : 94-107

Schneider , K. 2017. Entrepreneurial competencies of women entrepreneurs of micro and small enterprises. Science Journal of Education. 5 (6) : 252-261

Scott, C.E. 1986. Why more women are becoming entrepreneurs. Journal of Small Business Management. 37-44

Shah, H. 2013. Creating Enabling Environment for Women's Entrepreneurship in India. India: UNESCAP.

Shmiln, A. 2017. Female entrepreneurs in developing countries: A comparative with developed countries as explorative study. Arabian Journal of Business and Management Review. $7: 5$

Slee, R. 2005. From countrysides of production to countrysides of consumption?. The Journal of Agricultural Science. 143 (4) : 255-265

Sullivan, D.M \& W.R. Meek. 2012. Gender and entrepreneurship: A review and process model. Journal of Managerial Psychology. 27 (5) :428-458

Tambunan, T. 2008. Development of SME in ASEAN with reference to Indonesia and Thailand. Journal of Economics. 20 (10) : 53-83

Tambunan, T. 2009. Women entrepreneurship in Asian developing countries: Their development and main constraints. Journal of Development and Agricultural Economics. 1 (2): 27-40

Tambunan, T.T. 2017. Women Entrepreneurs in MSEs in Indonesia: Their motivations and main constraints. International Journal of Gender and Women's Studies. 5 (1) 88-100

Tur-Porcar, A., A. Mas-Tur \& J.A. Belso. 2017. Barriers to women entrepreneurship. different methods, different results? Quality Quantity. Journal Springer. 51 : 2019-2034 
Ufuk, H \& O. Ozgen. 2001. Interaction between the business and family lives of women entrepreneurs in Turkey. Journal of Business Ethics. 31 : 95-106

Wacht, S \& Gorgievski. 2016. More than Money Developing an Integrative Multi-factorial Measure of Entrepreneurial Success. International Small Bussiness Journal.
Welsh, D. H \& E. Kaciak. 2018. Business-family interface and the performance of women entrepreneurs: The moderating effect of economic development. International Journal of Emerging Markets.

Winn, J. 2004. Entrepreneurship: Not an easy path to top management for women. Women in Management Review. 19 (3) : 143-153 